\title{
Kentsel Gelişim ve Yeşil Alan Planlama Sürecinin Katılımcı Swot Analizi Yöntemi ile Değerlendirilmesi: Bingöl Kenti Örneği
}

Hüccet Vural ${ }^{1}$

ORCID: 0000-0001-6115-1572

\author{
Alperen $\mathrm{Meral}^{2}$ \\ ORCID: 0000-0001-6714-7187
}

\author{
Sülem Ş. Doğan ${ }^{3}$ \\ ORCID: 0000-0002-8370-4593
}

Öz

Değişen yaşam koşulları ve insanların ekonomik, sosyal ve kültürel ihtiyaçlarının kırsal yerleşim alanlarında karşılanamaması kentsel alanlara göçü meydana getirmiştir. Beklenmeyen nüfus artışları konut ihtiyacını ortaya çıkarmış ve kentlerin merkezden dışarıya doğru hızlı bir şekilde yayılmasına neden olmuştur. Kontrolsüz ve plansız yayılma özellikle açık ve yeşil alanlar, tarım alanları, meralar ve orman alanları gibi ekolojik yaşam alanları üzerinde önemli baskı unsuru haline gelmiştir. Bu durum aynı zamanda kent yönetimi sorununu da ortaya çıkarmıştır. Kent yönetimi kentsel hizmetlerin sunumundan kent yerleşiminin sağlıklı bir şekilde planlanmasına kadar birçok konuyu içeren bir kavramdır. Kentlerin yönetimi katılımo bir yaklaşımla uzun önemli planlama stratejilerinin oluşturulmasını ve şeffaf bir şekilde yönetilmesini zorunlu kılmaktadır. Bu çalışmada Bingöl İlinin kentleşme süreci ve yeşil alan planlaması ilişkisinin mevcut durumunu ortaya koymak, ekonomik, idari ve politik değişimler doğrultusunda kentleşme stratejilerini katılımcı yaklaşımla ele almak amaçlanmıştır. Araştırmada planlama yöntemi olarak kabul edilen SWOT (GZFT) ve TOWS (TFZG) analizi yöntemlerinden yararlanılmıştır. Farklı kurum temsilcilerinden oluşan 18 kişilik çalışma grubu ile yapılan SWOT analizinde Bingöl ilinin kentleşme-peyzaj ilişkisini etkileyen 62 içsel ve dışsal faktör belirlenmiştir. Bu faktörler amaçlı örnekleme yöntemi ile belirlenen 41 kişilik değerlendirme grubu tarafindan 0-4 puan arasında puanlanmıştır. Puanlama sonucuna göre zayıf yönler 2,93-3,73, güçlü yönler 1,66-2,59, firsatlar 1,95-3,07 ve tehditler ise 2,59-3,46 ortalama puan aralığında bulunmuştur. Elde edilen sonuçlar ve öncelikler doğrultusunda TOWS yöntemi kullanılarak araştırma alanı için sürdürülebilir kentleşme ve yeşil alan gelişim stratejileri önerilmiştir.

Anahtar Kelimeler: Bingöl, kentleşme, yeşil alan planlama, GZFT-TFZG, kentsel gelişim stratejisi.

\footnotetext{
${ }^{1}$ Dr. Öğr. Üyesi, Bingöl Üniversitesi, E-mail: hvural@bingol.edu.tr

${ }^{2}$ Arş. Gör., Bingöl Üniversitesi, E-mail: alperenmeral@bingol.edu.tr

${ }^{3}$ Arş. Gör., Bingöl Üniversitesi, E-mail: sulemsenyigit@hotmail.com idealkent @ Kent Araştırmaları Dergisi (Journal of Urban Studies) http://idealkentdergisi.com
} 


\title{
Assessment of Urban Development and Green Area Planning Process by Participant Swot Analysis Method: A Case of Bingol Province
}

*

\author{
Hüccet Vural 4 \\ ORCID: 0000-0001-6115-1572 \\ Alperen Meral $^{5}$ \\ ORCID: 0000-0001-6714-7187 \\ Sülem Ş. Doğan 6 \\ ORCID: 0000-0002-8370-4593
}

\begin{abstract}
The changing living conditions and the inability to meet the economic, social and cultural needs of the people in the rural areas, caused migration to urban areas. Unexpected population increases revealed the need for housing and caused the cities to spread rapidly from the city center to outside the city center. Uncontrolled and unplanned sprawl has become an important element of pressure on ecological habitats such as open-green areas, agricultural areas, pastures, and forest areas. This situation also revealed the problem of urban management. Urban management is a concept that includes many of the issues in a healthy way up to the planning of urban settlements from the provision of urban services. The urban management necessitates a long-term planning strategy with a participatory approach and transparent management. In this study, it is aimed to present the current state of the relationship between urbanization process and green area planning of Bingol Province and to examine urbanization strategies in line with economic, administrative and political changes with a participatory approach. SWOT and TOWS analysis methods, were used in the study, which is accepted as planning methods. In the SWOT analysis conducted with the 18-person working group consisting of representatives from different institutions, 62 internal and external factors affecting urbanization-landscape relationship were determined for Bingol city. These factors were scored between 0 and 4 points by the 41-person evaluation group. According to the score, the weaknesses were found to be 2.93-3.73, strengths 1.66-2.59, opportunities 1.953.07 and threats 2.59-3.46. According to the results and priorities, sustainable urbanization and greenfield development strategies have been proposed for the research area by using TOWS method.
\end{abstract}

Keywords: Bingol, urbanization, green space planning, SWOT-TOWS, urban development strategy.

\footnotetext{
${ }^{4}$ Asst. Prof., Bingöl University, E-mail: hvural@bingol.edu.tr

${ }^{5}$ Research Asst., Bingöl University, E-mail: alperenmeral@bingol.edu.tr

${ }^{6}$ Research Asst., Bingöl University, E-mail: sulemsenyigit@hotmail.com

idealkent @ C Kent Araştırmaları Dergisi (Journal of Urban Studies)

http://idealkentdergisi.com
}

Geliş Tarihi Received Date: 20.08.2019 Kabul Tarihi Accepted Date: 31.12.2019 


\section{Giriş}

Gerçek anlamda sanayi devrimi ile başladığı öngörülen kentleşmenin (Yılmaz ve Çitci, 2011, s.257; Güven, 2017, s.1048) 21. yüzyllın başında insanlık için üç temel zorluk ortaya çıkardığ artsşıdır. Günümüzde 7,53 milyar olan Dünya nüfusunun 2025 yılında 8,2 milyar, 2050 yılında 9 milyar seviyesine ulaşacağı öngörülmektedir. Diğer bir sorun kentleşme sorunudur. Günümüz nüfusunun yaklaşık \%60'1 kentsel alanlarda yaşamakta olduğu ve 2030 yılına kadar bu oranın üzerine çıkacağ şimdiden beklenmektedir. Üçüncüsü ise hızlı nüfus artışı ve kentleşmenin bir sonucu olarak ekosistemin bozulması sorunudur (Steiner, 2014, s.304). Türkiye'de ise 1950 li yıllarda nüfusun \%25 kentlerde yaşarken bu oran 1980 yılında \%44'e, 2000 yılında \%65'e, 2012 yılında \%77'ye ve 2016 yılında \%88'e yükselmiştir. 2050 yllında dünya nüfusunun üçte ikisinin, Türkiye nüfusunun \%95'inin şehirlerde yaşayacağı öngörülmektedir (Anonim,2017, s.9).

Geçmişten günümüze kentlerin sunduğu sosyal, kültürel ve ekonomik imkânlar kentlerin büyüme sürecine önemli etki etmiş ve bazı kentlerin kapasiteleri üzerinde büyümelerine neden olmuştur. Hızla artan kent nüfu$\mathrm{su}$, kentsel alanların sınırlarını genişletmiş ve yeni yerleşim alanlarının ortaya çıkmasını zorunlu kılmıştır (Anonim, 2016, s.24; Esen, 2019, s.104). Kentleşme artan nüfus nedeniyle oluşan konut talebi sonucunda kentin merkezden dişa doğru büyümesi, büyürken de mevcut kent dokusunun yenilenmesi ve genişlemesi anlamı taşımaktadır. Plansız, programsız ve rastgele yapılaşma ile kent dokusunun bozulması ve ekosistemin zarar görmesi ise çarpık kentleşmeyi ortaya çıkarmaktadır. Gelişigüzel, düzensiz ve kontrolsüz bir yapılaşma sonucunda bir taraftan kent dokusu tahrip edilirken diğer taraftan da doğal kaynakların (hava, su, toprak, çevre) bilinçsizce bozulmasina ve zarar görmesine sebep olunmaktadır (Aksoy ve Ergun, 2009, s.429). Ayrıca çarpık ve yayılmacı kentleşme ile kentin ekolojik yaşam alanları olan açı ve yeşil alanlar, tarım alanları, meralar ve orman alanları üzerinde baskılar oluşmaktadır. Çünkü yayılma ile şehir kenarlarında bulunan doğal ve yarı doğal alanlar ile mevcut yerleşim alanlarında bulunan açık alanların ve potansiyel yeşil alanların parçalanmasına ve yok olmasına sebep olunmaktadır (Gavrilidis, et al., 2019, s.67, Abo-El-Wafa, et al., 2019, s.309). Bu ise küresel ölçekte iklim değişikliği başta olmak üzere önemli çevresel problemlere yol açmaktadır.

Kentsel nüfus artışı ve yerleşim alanlarının genişlemesi sonucu oluşan çarpık ve düzensiz kentleşme kent yönetimi sorununu ortaya çıkarmıştır. 
Kent yönetimi kentin mali, beşeri, fiziki ve doğal kaynaklarının mevcut nüfusun ve gelecekteki nüfusun ihtiyaçları doğrultusunda en doğru ve en sağlıklı bir şekilde kullanılması ve yaşanabilir mekânlar oluşturmak için gerekli kararları alma, uygulama ve sonuçlarını denetleme işidir. Kent yönetimi kentsel hizmetlerin sunumundan kent yerleşiminin sağlıklı bir şekilde planlanmasına kadar birçok konuyu içeren bir kavramdır (Güven, 2017, s.1049). Günümüzde kent yönetimi katılımcllı̆ga ve şeffaflığa önem veren bir anlayışı zorunlu kılmaktadır. Paydaşların ekonomik, kültürel ve sosyal değerlerini göz önünde bulundurarak ihtiyaç ve gereksinimlerini karşılayan bir planlama anlayışı ortaya konulmalıdır. Bunun yanında kent yönetim plan ve politikalarının uzun dönemli ve şeffaf olması da sağlıklı bir kent oluşumunu sağlayacaktır. Türkiye'de kentlerin yönetimi merkezi hükümet politikaları doğrultusunda yerel yönetimler tarafından icra edilmektedir. Bu bakımdan kent yönetim planlamalarında yöreden yöreye değişen planlama politikalarını görmek mümkündür.

Avrupa Birliği'ne girme isteği ile birlikte Türkiye 2000'li yıllarda küreselleşmenin getirdiği sorunlarla mücadeleye başlamış ve kamu yönetimi alanında köklü bir yapılanmanın içerisine girmiştir. Kamu Yönetimi Temel Kanunu Tasarısı altında çeşitli reform paketleri ile yerel yönetimlere (Belediye ve İl Özel İdareleri) kentsel dönüşüme yönelik rol ve yükümlülükler verilmiştir (Özden, 2010, s.2). Ayrıca 2003 yılında çıkarılan 5018 sayılı “Kamu Mali Yönetimi ve Kontrol Kanunu" ile kamu yönetimlerine katılımcllığa ve şeffaflığa dayalı stratejik plan hazırlama zorunluluğu getirilmiştir. Bu kanunla beraber yerel, ulusal ve bölgesel ölçekte çok sayıda planın ve programın hazırlanarak uygulamaya konulduğu bilinmektedir. Özellikle son on yılda bu tür planların daha ağırlık kazandığı görülmektedir.

Mekânsal planlama ve imar konusunda en önemli yasal düzenleme 1985 yılında kanunlaşan 3194 sayılı İmar Kanunu'dur. Bu kanun bile kentleşmenin başladığı 1950 yılından yaklaşık 35 yıl sonraya dayanmaktadır. Mekânsal planlama süreci kalkınma planları temel alınarak bölge planları, metropoliten planlaması, alt bölge ve il planlaması, çevre düzeni planları, nazım ve uygulama imar planları, sektörel planlamalar olarak altı evrede incelenen bir süreci içermektedir (Anonim, 2012. s.2). Bu planlara ilave olarak kentsel yerleşmelerin mekânsal yaşam kalitesinin artırılması, ekonomik ve toplumsal yapının güçlendirilmesi, mekânsal planlama sisteminin yeniden yapılandırılması amacıyla "Orta Vadeli Program" ve AB Uyum Süreci kapsamında "2010-2023 Bütünleşik Kentsel Gelişme Stratejisi ve Eylem Planı-KENTGES" hazırlanmıştır. KENTGES, mekânsal planlama sisteminin 
yeniden yapılandırılması, yerleşmelerin mekân ve yaşam kalitesinin artıılması ve yerleşmelerin ekonomik ve toplumsal yapılarının güçlendirilmesi eksenleri üzerinde amaç, hedef ve stratejiler geliştirmektedir (Anonim, 2010, s.2-3). KENTGES; 2009 yılında Çevre ve Şehircilik Bakanlığı koordinasyonuyla 151 kurum ve kuruluştan 500 uzmanın katılımıla yapılan “Kentleşme Şurası" sonuçlarına dayanan şehirleşme ve imar vizyon belgesi olarak karşımıza çıkmaktadır. 2017 yılında yapılan Şehirleşme Şurası'nda ise oluşturulan dört komisyon tarafından "kimlikli şehirler", "Türkiye'nin yeni kentsel dönüşüm yaklaşımı", "toplumsal bütünleşme ve sosyal uyum", "güçlü yerel yönetimler ve şehircilik uygulamaları" konularına yönelik tedbirler ve mevzuat önerileri ortaya konulmuştur (Anonim, 2017, s.13).

Türkiye'de uygulanmakta olan kentsel planlamanın daha çok üst ölçekte ele alındığı, hazırlanan planların yerelde uygulanmasına yönelik sorunlar olduğu ve plan-program hedeflerine ulaşmakta sıkıntılar yaşandığı bilinmektedir. Üst ölçekli planlar doğrultusunda hazırlanmayan alt ölçekli planlar ülke kaynaklarının akılcı olmayan biçimde kullanılmasına yol açmaktadır. Nitekim kentlerimizde \%50'yi aşan hatta \%90'a kadar uzanan ruhsatsız, düzensiz ve yasal olmayan yapılaşma bunun en belirgin göstergesidir (Belde, 2006). Bunun yanında makro ölçekten mikro ölçeğe giden yeşil alan planlama stratejilerinin oluşturulmaması, halkın yeşil alan ihtiyacının günübirlik çözümlerle giderilmeye çalışılması ve mevcut yeşil alanların bir sistem bütünü içerisinde olmayıp birbirinden kopuk olması sağlıklı ve sürdürülebilir yeşil alan planlamasına engel olmaktadır (Manavoğlu ve Ortaçaşme, 2007, s.262).

Araştırma alanı olarak seçilen Bingöl'de de benzer durum söz konusudur. Kentin uzun dönemli sürdürülebilir kentleşme ve yeşil alan planlama stratejilerini ele alan resmi strateji belgesi ve bilimsel bir araştırmanın bulunmaması bu çalışmanın yapılmasına dayanak oluşturmuştur. Araştırmada Bingöl İlinin kentleşme süreci ve yeşil alan planlaması ilişkisinin mevcut durumunu ortaya koymak, ekonomik, idari ve politik değişimler doğrultusunda kentleşme stratejilerini katılımc yaklaşımla ele almak amaçlanmıştır. Ayrıca kentsel gelişim sürecinde kentleşme-peyzaj ilişkisini etkileyen içsel faktörlere bağl1 güçlü ve zayıf yönler ile dışsal faktörlerden kaynaklanan firsat ve tehditlerin belirlenmesi hedeflenmiştir. Araştırma sonuçlarının kentleşme ve yeşil alan planlaması konusunda hazırlanması muhtemel strateji belgelerine ve gelişim senaryolarına kaynak oluşturması öngörülmektedir. 


\section{Yöntem}

Araştırma Türkiye'nin Doğu Anadolu Bölgesi Yukarı Fırat bölümünde yer alan Bingöl ilinde gerçekleştirilmiştir. Kent doğuda Muş, kuzeyde Erzurum ve Erzincan, batısında Tunceli ve Elazı $\breve{g}$, güneyde ise Diyarbakır illeri ile komşudur. Bingöl İli $41^{\circ} 20$ ve $39^{\circ}-56^{\circ}$ doğu boylamları ile $39^{\circ}$ - 31 ve $36^{\circ}$ $28^{\circ}$ kuzey enlemleri arasında yer alır. Bingöl kenti karayolu ulaşımı açısından önemli konuma sahiptir. Kent merkezi içinden hem ulusal ve hem de uluslararası öneme sahip D300 karayolu geçmektedir.

Araştırmada yöntem olarak planlama ve strateji belirleme aracı olarak bilinen SWOT (GZFT) ve TOWS (TFZG) yöntemlerinden yararlanılmıştır. SWOT analizi bir bölge veya kurum ile ilgili bir konuda iç ve dış faktörleri analiz etmek ve mevcut durumunu ortaya koymak için kullanılan bir yöntemdir. Bu faktörler üstünlükler, zayıflıklar, firsatlar ve tehditler olarak dört grupta sinfflandırılmaktadır. TOWS analizi ise SWOT analizinde belirlenen faktörlerin değerlendirilerek geleceğe yönelik stratejilerin belirlendiği bir yöntemdir. Ancak bu yöntemlerin en bilinen sinurlılığ 1 karar faktörlerinin 23 kişilik küçük gruplarla belirlenmesi ve faktörlerin önem derecesinin say1sallaştırılmamasıdır. Araştırmada bu açığının giderilmesi amacıyla 18 kişilik çalışma grubu ve 41 kişilik değerlendirme grubu oluşturulmuştur. Çalışma ve değerlendirme grubunun belirlenmesinde amaçlı (yargısal) örneklemi yönteminden yararlanılmıştır. Amaçlı örneklemede araştırmacı kimlerin seçileceği konusunda kendi yargısını kullanır ve en uygun olanlarını çalışmaya dâhil eder.

\section{SWOT Analizinin Uygulanması}

SWOT analizinin uygulanması 18 kişilik çalışma grubunun katılımıyla gerçekleştirilmiştir. Çalışma grubuna konu ile ilgili farklı kurum ve kuruluş temsilcileri katılmıştır. Çalışmada fikir tepsisi uygulaması ile Bingöl ilinin kentleşme süreci ve yeşil alan planlamasını etkileyen olumlu ve olumsuz faktörler moderator eşliğinde belirlenmiştir. Çalışma başlamadan önce katılımcılara fikir vermek için araştırma konusu ile ilgili kavramların yer aldığı kelime bulutu oluşturulmuştur. Her bir katılımcıya kelime bulutunun yer aldığ1 A4 formları dağıtılmış ve katılımcılardan bir fikir yazmaları istenmiştir. Her bir komutla katılımcılar elinde bulundurduğu dönüt formunu yanındaki katılımcıya vererek yeni bir fikir yazmaları sağlanmıştır. Her bir komutta katılımcıların fikrini yazmaları için bir dakikalık süre verilmiş ve bu işlem $20 \mathrm{kez}$ tekrarlanmıştır. Dolayısıyla bir formda tüm katılımcıların 
fikirlerine yer verilmiş ve olumlu ve olumsuz faktörler ayrı ayrı olmak üzere toplam 720 fikir elde edilmiştir. Daha sonra olumlu ve olumsuz faktörler ayrı ayrı içerik analizine tabi tutulmuştur. Benzer cümleler çalışma grubu ile birlikte tek ifade haline getirilmiş ve katılımcların oylamasına sunulmuştur. Çalışma sonunda her bir fikrin ayrı ayrı oylanması ile 62 olumlu ve olumsuz faktör belirlenmiştir.

\section{Puanlama}

Çalışma grubunca belirlenen 62 olumlu ve olumsuz faktör araştırmacılar tarafından güçlü yön, zayıf yön, tehdit ve firsat olarak 4 gruba ayrılmıştır. Buna göre 23 zayıf yön, 13 güçlü yön, 14 fırsat ve 12 tehdit belirlenmiştir. Belirlenen faktörlerin kendi içerisinde öncelik ve üstünlüklerinin belirlenmesi amaciyla 41 kişilik değerlendirici grubun puanlamasına sunulmuştur. Puanlama 0-4 puan arasında yapılmış; " 0 " rakamı "belirtilen fikre hiç katılmadığını", "1, 2, 3, 4" rakamları ise katılma derecesini (1 düşük, 4 yüksek) belirtmek için kullanılmıştır. Puanlamaya katılanların 25'i (\%61) erkek, 16's1 (\%39) ise kadın katılımcılardan oluşmuştur. Katılımcılardan 20 kişi (\%49) yüksek lisans veya doktora mezunu, 21 kişi (\%51) ise lisans veya ön lisans mezunudur. Puanlama ile her bir faktöre ait ortalama ve standart sapma puanı hesaplanmış ve bu sonuçlar doğrultusunda kentleşme ve yeşil alan planlamasına yönelik sorun alanları-gelişim alanları ile bu sorunların çözümüne yönelik öncelikler belirlenmiştir.

\section{TOWS Matrisi Ve Strateji Analizi}

Genel olarak SWOT analizi mevcut durumu ortaya koymak, TOWS analizi ise geleceğe yönelik planlama stratejileri belirlemek için kullanılmaktadır. Araştırmada kentleşme-peyzaj ilişkisi ile ilgili planlama stratejileri belirlemek amacıyla Şekil 1'de verilen TOWS matrisi kullanılmıştır. Buna göre iç ve dış faktörlerin karşılıklı etkileşimi ile planlama stratejileri geliştirilmektedir.

\begin{tabular}{lll}
\hline & Güçlü Yönler & Zayıf Yönler \\
\hline Fırsatlar & $\begin{array}{l}\text { G-F stratejileri: Fursatlardan yararlan- } \\
\text { mak için güçlü yönlerini kullan }\end{array}$ & $\begin{array}{l}\text { Z-F stratejileri: zayıflığını yenmek için } \\
\text { fırsatları kullan }\end{array}$ \\
\hline Tehditler & $\begin{array}{l}\text { G-T stratejileri: tehditleri uzaklaştır- } \\
\text { mak için güçlü yönlerini kullan }\end{array}$ & $\begin{array}{l}\text { Z-T stratejileri: zayıf yönlerin ve tehditlerin } \\
\text { etkilerini en aza indir veya alandan çekil }\end{array}$ \\
\hline
\end{tabular}

Şekil 1. TOWS Matrisi 


\section{Bulgular}

Araştırma bulguları katılımcı yaklaşımla yapılan SWOT analizi sonuçlarını içermekle birlikte kentleşmeye neden olan nüfus verileri ve kentin fiziki gelişimi ile ilgili bulgulara da yer verilmiştir. Kentleşmeye esas nüfus verileri Türkiye İstatistik Kurumu (TÜIK) veri tabanlarına, kentin fiziki gelişimi ile ilgili veriler ise araştırma alanında daha önce yapılan benzer araştırma sonuçlarına dayanmaktadır.

\section{Demografik gelişmeler}

Kentleşmeye etki eden en temel faktör nüfus hareketliliğidir. Kentleşme ile nüfus arasındaki ilişkiyi açıklayabilmek için nüfusun hareketliliği, niteliği ve dağılımının uzun süreli olarak ele alınması gerekmektedir. Bir yerleşme bölgesinde meydana gelen nüfus yoğunluğu yeni yerleşim alanlarının ortaya çıkmasına neden olmaktadır. Araştırma alanı olarak ele alınan Bingöl İlinin TUIKK Adrese Dayalı Nüfus Kayıt Sistemi (ADNKS)'e göre 2018 yılı nüfusu 281.205 'dir. Bu nüfusun 168.180 'i kentsel (il ve ilçe merkezleri) bölgelerde, 113.025'i kırsal (belde, köy,...) bölgelerde ve 117.556's1 ise Bingöl kent merkezinde yaşamaktadır. 1968-2018 yıllarını kapsayan 58 yıllık döneme ait kentleşmeyi etkileyen temel nüfus verileri Tablo 1'de verilmiştir.

Tablo 1. Kentleşmeyi etkileyen temel nüfus verileri (TÜİ, 2019)

\begin{tabular}{|c|c|c|c|c|c|c|c|}
\hline Yil & $\begin{array}{l}\text { İl } \\
\text { Nüfus }\end{array}$ & $\begin{array}{l}\text { Kentli } \\
\text { Nufus } \\
\end{array}$ & $\begin{array}{l}\text { Kirsal } \\
\text { Nüfus }\end{array}$ & $\begin{array}{l}\text { Kent Merkezi } \\
\text { Nüfusu }\end{array}$ & $\begin{array}{l}\text { Kentleşme } \\
\text { Orani*(\%) }\end{array}$ & $\begin{array}{l}\text { Kentleşme } \\
\text { Orani**(\%) } \\
\end{array}$ & $\begin{array}{l}\text { Artış } \\
\text { oranı }^{* * *}(\%)\end{array}$ \\
\hline 1960 & 131.364 & 14.723 & 116.641 & 8.526 & 11,21 & 6,49 & \\
\hline 1965 & 150.521 & 20.401 & 130.120 & 11.727 & 13,55 & 7,79 & 37,54 \\
\hline 1970 & 177.951 & 35.451 & 142.500 & 17.220 & 19,92 & 9,68 & 46,84 \\
\hline 1975 & 210.804 & 45.961 & 164.843 & 22.047 & 21,80 & 10,46 & 28,03 \\
\hline 1980 & 228.702 & 54.997 & 173.705 & 28.146 & 24,05 & 12,31 & 27,66 \\
\hline 1985 & 241.548 & 61.199 & 180.349 & 34.024 & 25,34 & 14,09 & 20,88 \\
\hline 1990 & 250.966 & 86.648 & 164.318 & 41.590 & 34,53 & 16,57 & 22,24 \\
\hline 1997 & 234.790 & 127.518 & 107.272 & 67.022 & 54,31 & 28,55 & 61,15 \\
\hline 2000 & 253.739 & 123.470 & 130.269 & 68.876 & 48,66 & 27,14 & 2,77 \\
\hline 2007 & 251.552 & 141.703 & 109.849 & 86.511 & 56,33 & 34,39 & 25,60 \\
\hline 2008 & 256.091 & 137.286 & 118.805 & 86.113 & 53,61 & 33,63 & $-0,46$ \\
\hline 2009 & 255.745 & 138.574 & 117.171 & 89.224 & 54,18 & 34,89 & 3,61 \\
\hline 2010 & 255.170 & 138.069 & 117.101 & 87.918 & 54,11 & 34,45 & $-1,46$ \\
\hline 2011 & 262.263 & 147.081 & 115.182 & 95.669 & 56,08 & 36,48 & 8,82 \\
\hline 2012 & 262.507 & 150.166 & 112.341 & 98.424 & 57,20 & 37,49 & 2,88 \\
\hline 2013 & 265.514 & 150.556 & 114.958 & 99.260 & 56,70 & 37,38 & 0,85 \\
\hline 2014 & 266.019 & 155.697 & 110.322 & 103.441 & 58,53 & 38,88 & 4,21 \\
\hline 2015 & 267.184 & 160.614 & 106.570 & 108.267 & 60,11 & 40,52 & 4,67 \\
\hline 2016 & 269.560 & 167.917 & 101.643 & 111.364 & 62,29 & 41,31 & 2,86 \\
\hline 2017 & 273.354 & 175.824 & 97.530 & 117.014 & 64,32 & 42,81 & 5,07 \\
\hline 2018 & 281.205 & 168.180 & 113.025 & 117.556 & 59,81 & 41,80 & 0,46 \\
\hline
\end{tabular}

* Bingöl kentli nüfus oranı - ** Bingöl kent merkezi nüfusunun il nüfusuna oranı -

*** Kent merkezi nüfusunda meydana gelen artışın oranı 
Yukarıdaki verilere göre Bingöl ilinin nüfusu 1960 yılında 131.364 iken 2018 yılında \%114,07'lik artışla 281.205 olmuştur. Buna karşlık kent merkezi nüfusunun 58 yıllık süreçte 8.526 'dan 117.556 'ya yükseldiği ve \%1279'lik (yaklaşık 13 kat) artış meydana geldiği görülmektedir. Benzer olarak 1960 yılı Bingöl nüfusunun \%6,49'u kent merkezinde ikamet ederken 2018 yılında nüfusun $\% 41,80$ 'inin kent merkezinde yaşadığ kentleşme oranının ise $\% 11,21$ 'den $\% 59,81^{\prime}$ e yükseldiği görülmektedir. $\mathrm{Bu}$ iki veri birlikte değerlendirildiğinde Bingöl'de bir taraftan kentleşme oranı artarken diğer taraftan kent merkezi nüfus yoğunluğunun daha fazla yükseldiği görülmektedir. Kent merkezi nüfus artısında dönemlik bazda en fazla artıs 1965-1970 ve 1990-1997 yılları arasında, yıllık bazda ise 2011 y1lında $(\% 8,82)$ gerçekleşmiştir. Bingöl kent merkezi nüfus artış hızının yüksek olmasına karşıllk şehirleşme anlamında gelişimini henüz tamamlamamış orta büyüklükte bir kenttir (Kan, 2018, s.59). Kent merkezi nüfusunun artışında başta 1971 ve 2003 yılı depremleri olmak üzere 2007 yılında Bingöl Üniversitesi'nin kurulması, kamu kurumlarının yaygınlaşması, tarım ve sanayide meydana gelen gelişmeler, sosyal, ulaşım ve sağlık sektöründe meydana gelen olumlu gelişmelerin etkisi olduğu bilinmektedir (Üstündağ, 2011, s.91; Kan, 2018, s.59; Doğan ve Yılmaz, 2019, s.543).

\section{Kentin Fiziki Gelişimi}

Araştırma alanı olarak belirlenen Bingöl'ün tarihsel süreçte yerleşiminin M.Ö. 3500 yıllarına dayandığı tarihi belgelerle ortaya konulmuştur. İlk yerleşim yeri olarak günümüz kentsel yerleşim alanı içerisinde yer alan Çapakçur Vadisi civarında oluştuğu ve 1936 yılına kadar Çapakçur olarak adlandırıldığı görülmektedir. 7 Aralık 1935 'te kabul edilen ve 04.01.1936 tarihli Resmi Gazete'de ilan edilen 2885 sayılı kanun ile Bingöl adında bir il kurulmuş, Çapakçur ise Bingöl merkez ilçenin ismi olarak tescillenmiştir. 1945 yılında Çapakçur ismi de kaldırılarak Bingöl hem merkez ilçe adı, hem de il adı olarak kullanılmaya başlanmıştır (Üstündağ, 2011, s.85). Günümüzde Çapakçur, kentin ortasından geçen Çapakçur çayı ve vadisi içerisinde kalan eski yerleşimin adı olarak kalmıştır. Çapakçur vadisinin Bingöl'ün kentleşme sürecinde belirleyici rol oynadığı görülmektedir.

Bingöl kent merkezi Çapakçur vadisinin güney yamacında kurulmuş, kentin nüfus artışına paralel olarak vadinin iki yakasında bulunan taraçalar üzerinde gelişmiştir (Kan, 2018, s.62). Tarihsel süreç içerisinde önemli doğal olaylar (deprem, sel, heyelan, vb...) nedeniyle kent merkezinin konumu 
değişmesine rağmen genel olarak Çapakçur çayının kenarlarında mahallelerin oluştuğu görülmüştür (Üstündă̆, 2011, s.88). Bingöl'ün vilayet olarak ilan edildiği 1936 yılında kent merkezi olarak Çapakçur vadisi içerisinde bulunan ve aşağı çarşı olarak adlandırılan bölgenin kullanıldığı belirlenmiştir (Şekil 2). Nüfus artışı, kentleşme bilincinin oluşması, jeolojik ve jeomorfolojik oluşumlardan dolayı kentleşmenin zamanla vadinin iki yakasında bulunan taraçalar üzerine doğru kaydığ 1 belirlenmiştir. 1935-1955 yılları arasında vadi boyunca doğu-batı yönünde dikey olarak yapılan şehirleşme daha sonra güney taraça üzerine doğru kaymıştır (Üstündağ, 2011, s.83, Kan, 2018, s.47). Bu yer değiştirmede vadi yamaçlarından yerleşim bölgelerine olan yoğun toprak kayması ve kaya düşmelerinin de etkili olduğu vurgulanmaktadır (Soylu, 2009, s.90).

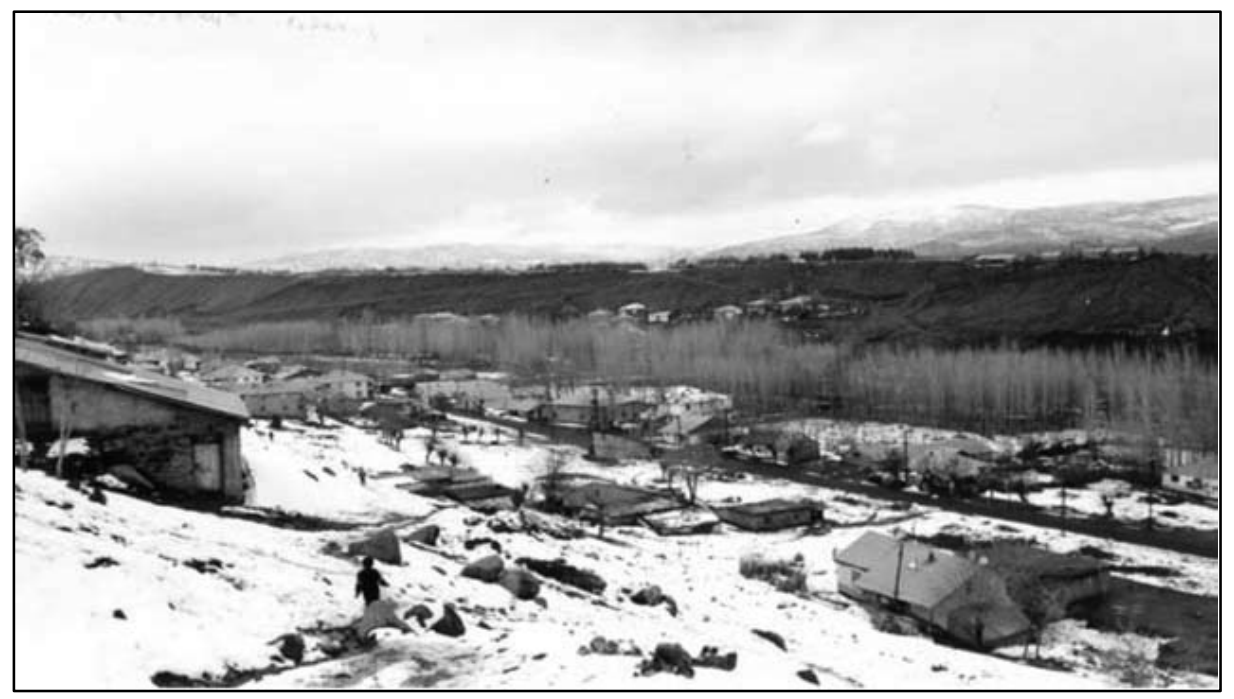

Şekil 2. Çapakçur vadisinde yer alan eski Bingöl/Çapakçur'dan bir görünüm (Soylu, 2009, s.90)

1965 yılından günümüze kadar Bingöl kent merkezi nüfusunda meydana gelen yüksek oranlı artış ile kentin yerleşim alanlarında hızlı bir büyüme meydana gelmiştir (Şekil 3). Bingöl'ün kentleşme sürecinde ilk imar planı 22.10.1965 tarihinde yürürlüğe girmiştir. Bu imar planı ile vadi içerisinde yerleşimlerin uygun olmadığı belirlenmiş, Bahçelievler, Karşıyaka, İnönü ve Kültür mahalleleri için imar uygulamalarına yer verilmiştir. 1971 depremi ile hem yeni imar planına hem de yeni yerleşim alanlarına ihtiyaç duyulmuştur. Bu tarihten sonra kentin gelişimi Çapakçur vadisinin güneyinde 
Genç yolu kenarında bulunan düz alanlara doğru kaydırılmıştır (Üstündağ, 2011, s.83). Resmi kurumlar ise vadinin kuzeyinde Elazığ-Bingöl karayolu paralelinde konumlandırılmıştır. Daha sonra 1976 yılında ek imar planı ile şehrin gelişimi Bingöl-Muş karayolu üzerine ve doğuya doğru biçimlendirilmiştir (Kan, 2018, s.47).

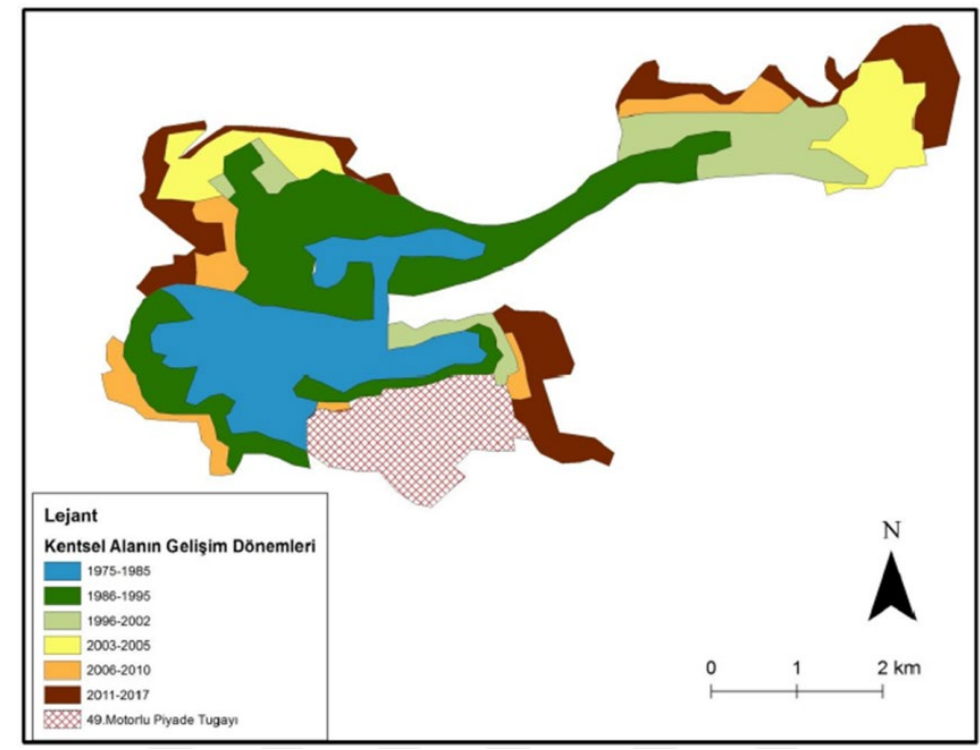

Şekil 3. Bingöl kentinin fiziki gelişim süreci (Kan, 2018, s.46)

1983 yılında kentin artan iç göç neticesinde yeni yerleşim alanı ihtiyacını karşılamak ve günün mevcut koşullar altında en uygun gelişim aksını belirlemek amacıyla İller Bankası tarafından günümüzde halen daha kullanılmakta olan uygulama imar planı hazırlanmış ve yürürlüğe konulmuştur. 1975-2000'li yıllarda İnalı ve Saray mahalleleri ile kentin genişleme serüveni devam etmiştir (Kan, 2018, s.48). Bingöl'de makro ölçekte büyüme 19852000 yılları ile 2000-2017 yılları arasında iki dönemde meydana gelmiştir. Birinci dönemde kent daha çok batıya, ikinci dönemde ise kuzey, güney ve doğuya doğru büyümüştür (Esen, 2019, s.107). 1985 yılında kentin yerleşim alanları 361,69 ha yüz ölçümüne sahipken 2019 yılında 593,76 (ha)a yükselmiştir (Şekil 4). 34 yıllık süreçte yerleşim alanlarında \%142'lik bir artış hesaplanmıştır. Kentin bugünkü fiziki gelişiminde 2003 yılı depremi ile 2007 yılında Bingöl Üniversitesinin kurulması çok önemli rol almıştır. Recep Tayyip Erdoğan, Şehit Mustafa Gündoğdu, Kaleönü ve İçmeler mahallelerinin kurulması bu tarihlerden sonraya denk gelmektedir. 

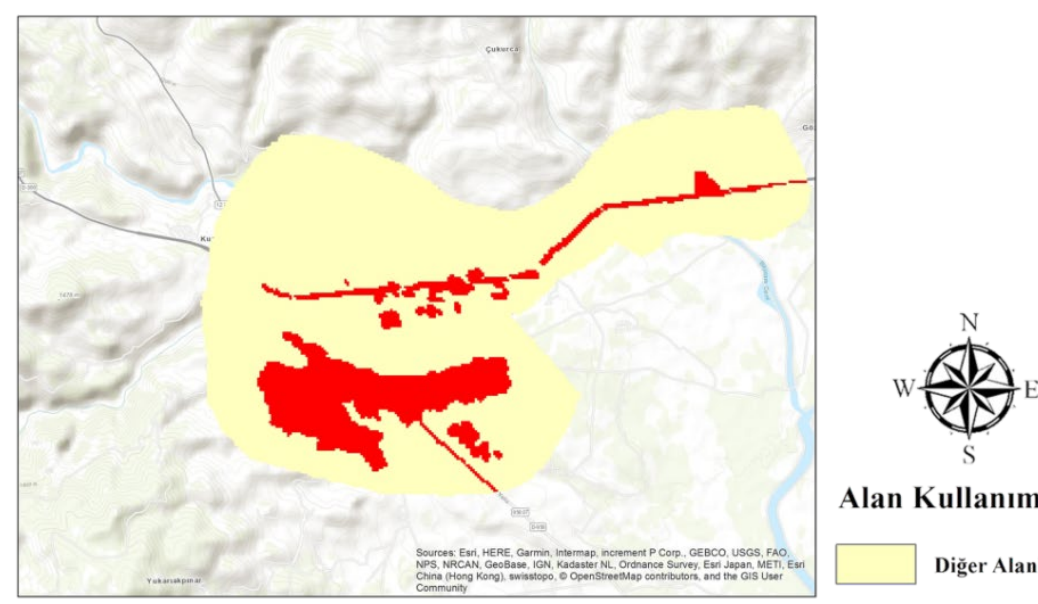

Alan Kullanımları
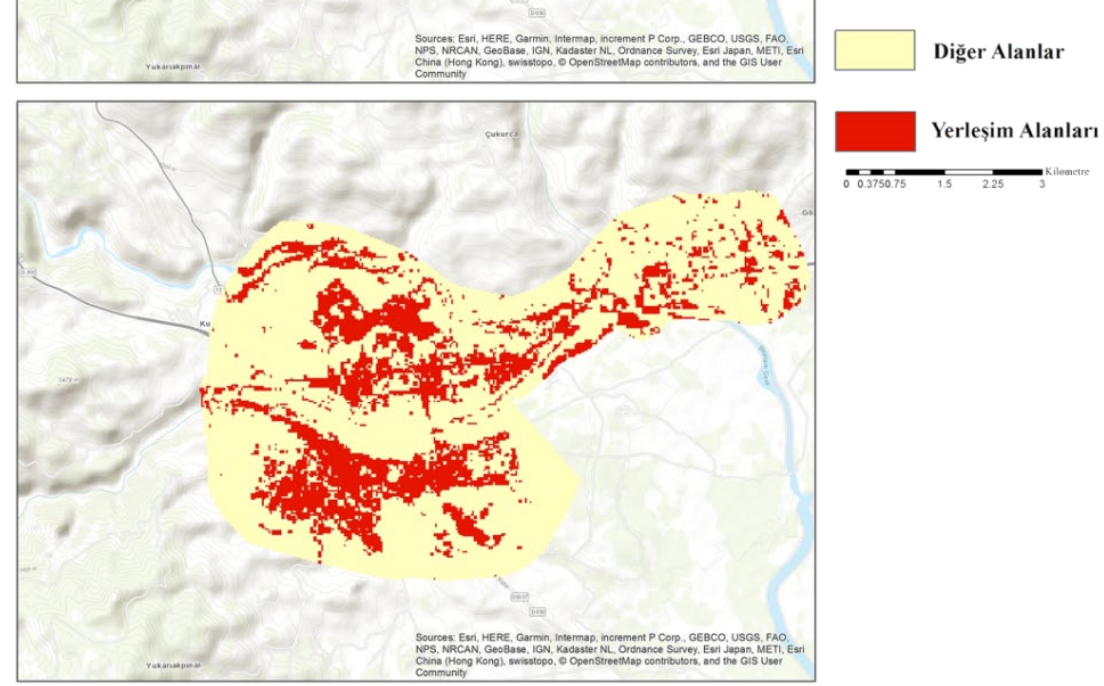

Şekil 4. Bingöl kentinin 1985-2019 yılları arasında yerleşim alanlarının değişim haritası

Araştırma alanının günümüz kentleşme durumu için gelişimden çok dönüşümünden bahsetmek daha doğru olur. Kentte büyük oranda kentsel dönüşüm projelerinin uygulandığı görülmektedir. Özellikle Şehit Mustafa Gündoğdu, Mirzan ve Karşıyaka mahallelerinde eski binaların yerini yüksek katlı binalara bıraktı̆̆ göze çarpmaktadır. 2003 depremi sonrasında yapılan iki katlı deprem evlerinin yerine yeni konutların yapıldı̆̆ı görülmektedir. Ancak yeni yapılaşmada rastgele ve gelişigüzel bir yapılanmanın olduğu ve bunun sonucu olarak düzensiz ve çarpık yapılaşmanın giderek kendini hissettirdiği belirlenmiştir. Kentin bugünkü fiziki durumu ile ilgili görünümler Şekil 5'de verilmiştir. 


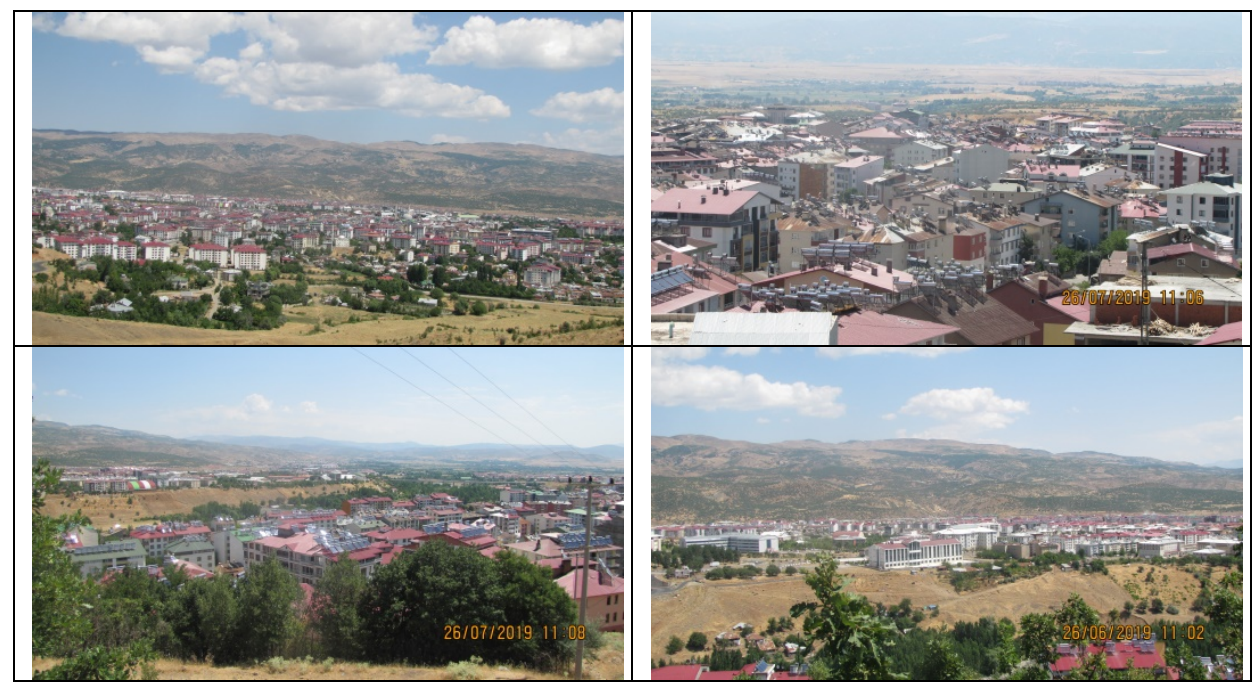

Şekil 5. Bingöl kentinin günümüzde ki durumu

\section{SWOT (GZFT) Analizi Sonuçlan}

Araştırma alanının kentleşme ve yeşil alan planlama sürecini etkileyen içsel ve dışsal faktörlerin belirlenmesi amacıyla SWOT analizi yapılmıştır. 18 kişilik çalışma grubu tarafından belirlenen içsel ve dışsal faktörlerin kendi içerisinde önceliklendirilmesi amacıyla 41 kişilik değerlendirici grup tarafından yapılan puanlamada aşağıdaki sonuçlar elde edilmiştir.

İçsel faktörler (Güçlü-zayıf yönler): İçsel faktörler güçlü ve zayıf yönler olarak kategorileştirilmiştir. Araştırma alanının kentleşme ve yeşil alan planlama sürecinde etkili olan 23 zayıf yön ve 13 güçlü yön belirlenmiş olup araştırmaya katılan değerlendirme grubu tarafindan önceliklendirilmiştir. Buna göre araştırma alanında kentleşme ve yeşil alan planlama sürecinde karşılaşılan olumsuzluklar ve geliştirilmesi gereken alanlara ilişkin zayıf yönlere değerlendirici grup tarafından verilen puanların ortalamaları ve standart sapma değerleri Tablo 2' de verilmiştir. 
Tablo 2. Bingöl kentleşme ve yeşil alan planlama süreci SWOT analiz sonuçları-zayıf yönler

\begin{tabular}{|c|c|c|c|}
\hline S.N & Zayıf yönler & Ort. & S.s \\
\hline Z1 & Çarpık ve plansız yapılaşma & 3,73 & 0,55 \\
\hline $\mathrm{Z} 2$ & $\begin{array}{l}\text { Kentsel yeşil alanların nitelik ve nicelik bakımdan yetersizliği, kullanıcı } \\
\text { isteklerini karşılayamaması }\end{array}$ & 3,71 & 0,65 \\
\hline $\mathrm{Z} 3$ & $\begin{array}{l}\text { Yerel yönetimlerin örgütlenme yapısındaki eksiklikler, planlama ile } \\
\text { ilgili mevzuatın uygulanamaması }\end{array}$ & 3,68 & 0,53 \\
\hline $\mathrm{Z} 4$ & Kent ekolojisi gözetilmeksizin yapılan planlamalar & 3,66 & 0,70 \\
\hline $\mathrm{Z} 5$ & Kent kimliğini - kent imajını yansıtacak fiziki çalışmaların yetersiz oluşu & 3,63 & 0,63 \\
\hline Z6 & $\begin{array}{l}\text { Konut alanlarında yeterli yeşil alanlara yer verilmemesi, } \\
\text { bu konuda mevcut mevzuatın uygulanmaması }\end{array}$ & 3,56 & 0,81 \\
\hline $\mathrm{Z7}$ & $\begin{array}{l}\text { Kent yakını mesire (rekreasyon) alanlarının yetersizliği ve bu ihtiyacın } \\
\text { kent merkezindeki yeşil alanlardan karşılanma isteği sonucu yeşil alanların } \\
\text { amacı dışında kullanılması }\end{array}$ & 3,51 & 0,78 \\
\hline $\mathrm{Z8}$ & $\begin{array}{l}\text { Kent için kurgulanmış yeşil altyapı sisteminin bulunmaması, } \\
\text { yeşil alanların kent içindeki dağılımında ve erişimlerdeki eşitsizlikler }\end{array}$ & 3,51 & 0,84 \\
\hline Z9 & $\begin{array}{l}\text { Mevcut su kaynaklarının (Çapakçur, Gayt derelerinin) kent } \\
\text { peyzajının planlanmasında yeterince etkili kullanılmaması }\end{array}$ & 3,49 & 0,90 \\
\hline Z10 & Kent yakınında bulunan doğal kaynakların bilinçsizce tahribatı & 3,44 & 0,71 \\
\hline Z11 & $\begin{array}{l}\text { Yerel yönetimlerde kentleşme ve yeşil alan planlamasında uzman t } \\
\text { eknik personel eksiklikleri }\end{array}$ & 3,41 & 0,71 \\
\hline $\mathrm{Z} 12$ & Kent için uzun dönemli planlama stratejilerinin bulunmaması & 3,39 & 0,92 \\
\hline Z13 & $\begin{array}{l}\text { Kent genelinde kamusal alanlarda yapılan fiziki düzenlemelerde } \\
\text { "Herkes İçin Tasarım, Evrensel Tasarım" ilkelerine ve s } \\
\text { tandartlarına uygun planlamanın olmayışı, }\end{array}$ & 3,39 & 0,92 \\
\hline Z14 & Kentsel altyapı sorunları & 3,39 & 0,80 \\
\hline Z15 & $\begin{array}{l}\text { Kentleşme ve yeşil alanlar konusunda çalışma yapacak sivil toplum } \\
\text { örgütlenmesinin olmayışı, bu konuda yeterli kamuoyu bilincinin } \\
\text { oluşturulamaması }\end{array}$ & 3,39 & 0,77 \\
\hline Z16 & Sosyal ve sportif faaliyet alanlarının azlığı & 3,39 & 0,86 \\
\hline $\mathrm{Z} 17$ & $\begin{array}{l}\text { Doğal afetlerin (sel, deprem, taşkın) etkilerini azaltmaya ve } \\
\text { önlemeye yönelik planlama yetersizlikleri }\end{array}$ & 3,39 & 0,83 \\
\hline Z18 & $\begin{array}{l}\text { Kent genelinde ve yeşil alanlarda kullanılan kent mobilyalarının sayı ve } \\
\text { nitelik bakımından yetersizliği }\end{array}$ & 3,39 & 0,89 \\
\hline Z19 & $\begin{array}{l}\text { Donatı (aydınlatma, yönlendirme levhaları, tabelalar) yetersizliklerinin } \\
\text { güvenlik sorunlarına yol açması }\end{array}$ & 3,34 & 0,91 \\
\hline $\mathrm{Z} 20$ & Kent içi araç-yaya trafik sirkülasyonunun iyi kurgulanmamış olması, & 3,29 & 0,93 \\
\hline $\mathrm{Z} 21$ & Süs bitkisi üretim alanlarının, fidanlıkların yetersiz oluşu & 3,20 & 1,03 \\
\hline $\mathrm{Z} 22$ & $\begin{array}{l}\text { Akıllı kent uygulamalarından ve teknolojik yeniliklerden } \\
\text { yararlanılamaması }\end{array}$ & 3,05 & 0,97 \\
\hline $\mathrm{Z} 23$ & $\begin{array}{l}\text { Otopark alanı yetersizliği ve düzensiz park yüzünden ulaşımda meydana } \\
\text { gelen aksamalar }\end{array}$ & 2,93 & 1,25 \\
\hline
\end{tabular}

Tablo 2'de ki sonuçlar incelendiğinde zayıf yönlerin katılımcılar tarafından ortalama 3,73 ile 2,93 arasında puanlandığı görülmektedir. Dört puan üzerinden yapılan değerlendirmede zayıf yönlere ilişkin sonuçların birbirine yakın olduğu ve katılımcların bu fikirleri yüksek oranda destekledikleri belirlenmiştir. Katılımclar kentte çarpık ve plansız yapılaşmayı en yüksek oranda zayıf yön olarak belirlerken otopark 
yetersizliği ve ulaşımda meydana gelen aksamaları daha düşük oranda zayıf yön olarak görmektedir. Bunun yanında kentin ekolojik altyapısını oluşturan yeşil alanların nitelik ve nicelik bakımdan yetersizliğini içeren faktörlerin yüksek oranda zayıf yön olarak değerlendirildiği belirlenmiştir. Belirlenen 23 zayıf yönün dört tanesinin kent planlaması ile, yedi tanesinin ekolojik planlama ile, altı tanesinin kent alt yapısı ile ve altı tanesinin ise kentin kurumsal kapasite ile ilgili olduğu görülmektedir.

İçsel faktörler içerisinde değerlendirilen diğer bir faktör güçlü yönlerdir. Güçlü yönler başarılan ve olumlu görülen alanları kapsamaktadır. Çalışma grubu tarafından belirlenen 13 güçlü yön değerlendirme grubu tarafından puanlanmış ve puanlama sonuçları Tablo 3'de verilmiştir.

Tablo 3.Bingöl kentleşme ve yeşil alan planlama süreci SWOT analiz sonuçları-güçlü yönler

\begin{tabular}{llcc}
\hline S.N & Güçlü yönler & Ort. & S.s \\
\hline G1 & $\begin{array}{l}\text { Kentin doğal yapısının yeşil ve mavi altyapı sisteminin } \\
\text { kurgulanmasına uygun olması }\end{array}$ & 2,59 & 1,41 \\
\hline G2 & Kent güvenliği ve huzuru konusunda olumlu atmosferin olması & 2,39 & 1,12 \\
\hline G3 & Kentsel dönüşüm çalışmaları ile kentin yenilenme sürecinde olması & 2,32 & 1,25 \\
\hline G4 & $\begin{array}{l}\text { Kent merkezinde aktif yeşil alana dönüştürülebilecek açık } \\
\text { alanların fazlalığı }\end{array}$ & 2,17 & 1,40 \\
\hline G5 & Yakın bölge kentlerine göre gecekondulaşmanın daha az olması & 2,17 & 1,14 \\
\hline G6 & Kent yakınında tarım alanlarının fazlalığı & 2,12 & 1,45 \\
\hline G7 & Kentte yüksek katlı yapılaşmaya izin verilmemesi & 2,07 & 1,33 \\
\hline G8 & Kentlilik bilincinin her geçen gün artması, kentin değişime açık olması & 2,00 & 1,18 \\
\hline G9 & $\begin{array}{l}\text { Kent yakını doğal peyzaj alanlarının ve rekreasyon amaçlı orman } \\
\text { alanlarının varlığı ve korunmuş olması }\end{array}$ & 1,95 & 1,30 \\
\hline G10 & $\begin{array}{l}\text { Kent yakını tarım alanlarının imara kapatılması, yapılaşmaya } \\
\text { izin verilmemesi }\end{array}$ & 1,90 & 1,43 \\
\hline G11 & $\begin{array}{l}\text { Kadınların kişisel gelişimi konusunda faaliyet gösteren } \\
\text { sivil toplum örgütlerinin bulunması ve kentin farklı sorunları } \\
\text { konusunda faaliyetler yürütmesi }\end{array}$ & 1,83 & 1,22 \\
\hline G12 & Halkın yeşil alan ve doğaya karşı olumlu tutum göstermesi & 1,78 & 1,35 \\
\hline G13 & Marka kent oluşumu yönünde kamuoyu talepleri & 1,66 & 1,20 \\
\hline
\end{tabular}

Katılımcıların güçlü yönlere verdiği puanların ortalamalarının 2,59 ile 1,66 puan arasında olduğu belirlenmiştir. Zayıf yönlere göre hem sayı hem de puan ortalaması bakımından daha düşük olan güçlü yönlerin dört tanesinin kent planlaması ile, beş tanesinin ekolojik planlama ile ve dört tanesinin ise kentin kurumsal kapasite ile ilgili olduğu görülmektedir. Kentin doğal yapısının mavi ve yeşil alt yapıya uygun olması en yüksek güçlü yönü, marka kent oluşumu konusunda kamuoyu talepleri en düşük oranlı güçlü yönü ifade etmektedir. Güçlü yönler kentleşme sürecinde mutlaka korunması ve geliştirilmesi gereken faktörleri içermektedir. 
Dışsal faktörler (Firsatlar-Tehditler): Dışsal faktör olarak değerlendirilen firsat ve tehditler üzerinde çalışılan konu üzerinde doğrudan etkisi bulunmamakla birlikte mutlaka göz önünde bulundurulması gereken faktörlerdendir. Planlamada zayıf yönlerin iyileştirilmesi için firsatlardan yararlanılırken, tehditlerin ise sürekli kontrol altında tutulması önerilir. Bu bakımdan Bingöl ilinin kentleşme sürecinde göz önünde bulundurulması gereken firsat ve tehditler belirlenmiştir. Dışsal faktörlerden planlama sürecini olumlu olarak etkileyeceği değerlendirilen fırsatlar ve buna ilişkin sayısal sonuçlar Tablo 4' de verilmiştir.

Tablo 4. Bingöl kentleşme ve yeşil alan planlama süreci SWOT analiz sonuçları-fırsatlar

\begin{tabular}{llcc}
\hline S.N & Firsatlar & Ort. & S.s \\
\hline F1 & Kentin coğrafi konumunun elverişli olması ve büyükşehirlere yakınlı̆̆ı & 3,07 & 1,03 \\
\hline F2 & $\begin{array}{l}\text { Farklı turizm alternatiflerine uygun olanaklarının bulunması (kış turizmi, } \\
\text { termal turizm, yayla turizmi, güneşin doğuşu-kültür turizmi) }\end{array}$ & 2,71 & 1,23 \\
\hline F3 & $\begin{array}{l}\text { Çeşitli kurumlar tarafından (Fırat Kalkınma Ajansı, Doğu Anadolu Projesi } \\
\text { (DAP) Bölge Kalkınma İdaresi Başkanlığı, ..) kentin gelişimine katkı sağlaya- } \\
\text { cak ekonomik teşvikler }\end{array}$ & 2,71 & 1,06 \\
\hline F4 & $\begin{array}{l}\text { Bingöl Üniversitesinin kentin ekonomik, sosyal ve kültürel gelişimine katkı } \\
\text { sağlaması }\end{array}$ & 2,71 & 1,19 \\
\hline F5 & $\begin{array}{l}\text { Üniversitede kentleşme, doğal kaynaklar ve yeşil alan yönetimleri konusunda } \\
\text { çalışılan programların bulunması }\end{array}$ & 2,68 & 1,35 \\
\hline F6 & $\begin{array}{l}\text { Kentleşme ve yeşil alan planlamasına yönelik mevzuatın olması ve yerel } \\
\text { yönetimlere çeşitli yetkilerin verilmiş olması }\end{array}$ & 2,61 & 1,26 \\
\hline F7 & $\begin{array}{l}\text { Kent merkezi ve yakın çevresinde rekreasyonel aktivitelere katkı sağlayacak } \\
\text { doğal peyzaj elemanlarının (orman, dağ, akarsu, dere, baraj ve göller) varlı̆̆1 }\end{array}$ & 2,46 & 1,47 \\
\hline F8 & Geçiş bölgesi olması nedeniyle zengin floraya sahip olunması & 2,39 & 1,32 \\
\hline F9 & $\begin{array}{l}\text { Jeotermal kaynakların fazlalığı (Seracılık faaliyetleri açısından değerlendiril- } \\
\text { mesi) }\end{array}$ & 2,39 & 1,24 \\
\hline F10 & Kalkınmada öncelikli iller arasında olunması & 2,27 & 1,23 \\
\hline F11 & Zengin mera alanlarına sahip olunması & 2,20 & 0,95 \\
\hline F12 & Nüfus yoğunluğunun az, genç nüfusun fazla olması & 2,17 & 1,18 \\
\hline F13 & $\begin{array}{l}\text { Mikro havza planlama çalışmaları ile bölgesel doğal kaynak yönetim strateji- } \\
\text { lerinin oluşturulması }\end{array}$ & 2,00 & 1,20 \\
\hline F14 & Kentin tarihi ticaret yollarının kesişim noktasında bulunması & 1,95 & 1,32 \\
\hline
\end{tabular}

Dışsal faktörler olarak ele alınan 14 fırsat faktörü 3,07 ile 1,95 arasında önemli bulunmuştur. Katılımcilar kentin coğrafi konumu ve büyükşehirlere olan yakınlığını en güçlü faktör olarak kabul etmişken, kentin tarihi ticaret yolları üzerinde bulunmasını en az etkili fırsat olarak kabul etmiştir. Fırsatları coğrafi, mali, kamusal kapasite, doğal kaynaklar ve demografik faktörler olarak sınıflandırılırsa özellikle Bingöl'ün sahip olduğu doğal kaynak faktörlerinin en önemli firsat olarak görüldüğü belirlenmiştir. $\mathrm{Bu}$ 
bakımdan doğal kaynakların kentleşme ve yeşil alan planlama sürecine katkı sağlayacak stratejiler üzerinde çalışılabileceğini göstermektedir.

Dişsal faktörler içerisinde değerlendirilen diğer bir faktör tehditlerdir. Tehditler planlama sürecinin en zor ve etkili faktörlerindendir. Araştırma konusunu etkileyebileceği düşünülen temel tehdit faktörleri Tablo 5'de verilmiştir. 12 tehdit bulgusu 3,46 ile 2,66 arasında puanlandığı ve oranlarının yüksek olduğu belirlenmiştir. En önemli tehdit unsuru olarak katılımcılar kentte yapılaşma ve rant baskısını, en düşük tehdit faktörü olarak nüfus hareketleri ve nitelikli göç unsurunu bulmaktadır. Belirlenen 12 tehdit unsurunun geçmişten günümüze Bingöl'ün kentleşme sürecinde önemli rol oynadığı belirlenmiştir.

Tablo 5. Bingöl kentleşme ve yeşil alan planlama süreci SWOT analiz sonuçları-tehditler

\begin{tabular}{llrc}
\hline S.N & Tehditler & Ort & S.s \\
\hline \multirow{2}{*}{ T1 } & $\begin{array}{l}\text { Kentsel dönüşüm üzerinde plansız ve uygun olmayan yapılaşma bask1- } \\
\text { S1, rant sağlama talepleri }\end{array}$ & 3,46 & 0,78 \\
\hline \multirow{2}{*}{ T2 } & $\begin{array}{l}\text { Kent yakınında bulanan tarım alanları üzerinde amaç dışı kullanım } \\
\text { baskısı (yapılaşma, rekreasyon,...) ve verimli tarım topraklarının koru- } \\
\text { namaması, }\end{array}$ & 3,46 & 0,75 \\
\hline T3 & Ağır geçen kış koşulları sonucunda meydana gelen alt yapı sorunları & 3,41 & 0,77 \\
\hline T4 & Doğal afet riskleri, özellikle kentin 1. derece deprem bölgesinde olması & 3,39 & 0,97 \\
\hline T5 & Coğrafi yapının kentsel gelişim yönünü sınırlandırması & 3,27 & 0,95 \\
\hline T6 & Kent merkezinde turizm cazibe alanlarının bulunmaması & 3,27 & 0,81 \\
\hline \multirow{2}{*}{ T7 } & $\begin{array}{l}\text { Doğal kaynakların sürdürülebilir kullanımına ilişkin doğal kaynak } \\
\text { koruma politikalarının yetersizliği }\end{array}$ & 3,27 & 1,03 \\
\hline T8 & Mali kaynak yetersizlikleri, mevcut kaynakların iyi değerlendirilememesi & 3,17 & 0,83 \\
\hline T9 & Giderek artan çevre, hava, gürültü ve görüntü kirliliği & 3,12 & 0,90 \\
\hline T10 & Eğitim olanakları ve sağlık hizmetlerinin yetersizliği & 3,12 & 0,91 \\
\hline \multirow{2}{*}{ T11 } & $\begin{array}{l}\text { Çevre yolunun kent içinden geçmesi (kent planlamasındaki bütünlüğün } \\
\text { sağlanamaması) }\end{array}$ & 2,88 & 0,84 \\
\hline T12 & Sikça yaşanan nüfus hareketleri, nitelikli göç verilmesi & 2,66 & 1,06 \\
\hline & & &
\end{tabular}

\section{Gelişim stratejileri}

Bu kısımda araştırma alanı için göz önünde bulundurulması önerilen kentleşme ve yeşil alan planlama stratejileri belirlenmiştir. Stratejilerin belirlenmesinde SWOT analiz sonuçlarına dayanarak oluşturulan TOWS matrisi kullanılmıştır. Araştırma alanı için içsel ve dışsal faktörlerin çakıştıılması ile elde edilen 12 adet kentleşme ve yeşil alan planlama stratejisi örnek olarak belirlenmiş ve Tablo 6'da verilmiştir. Şüphesiz ki araştırma alanı için geliştirilebilecek kentleşme stratejileri bunlarla sınırlı değildir. Özellikle zayıf yönlerin iyileştirilmesinde fırsatların değerlendirilmesi, mevcut güçlü yönlerle tehditlerin etkisini azaltma, firsat ve güçlü yönlerin birlikte değerlendirile- 
rek daha güçlü stratejilerin oluşturulması mümkündür. Stratejilerin belirlenmesinde en riskli alan zayıf yön ve tehditlerin ele alındığ $\mathrm{Z}$-T stratejileridir. Burada zayıf yön ve tehditlerin etkisini azaltmaya yönelik tedbirler ele alınmaktadır.

Tablo 6. Gelişim stratejileri (TOWS analiz sonuçları)

\begin{tabular}{|c|c|c|}
\hline & Güçlü Yönler & Zayıf Yönler \\
\hline 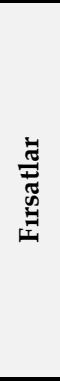 & $\begin{array}{l}\text { G-F stratejileri } \\
\text { 1.Sağllkl kentleşme için sürdürülebilir } \\
\text { mavi ve yeşil alt yapı sisteminin kurgu- } \\
\text { lanması stratejisi (G1-F5). } \\
\text { 2.Mevcut yasal düzenlemeler ile kentsel } \\
\text { dönüşüm ve marka kent oluşumu strate- } \\
\text { jisi (G3-F6). } \\
\text { 3.Kadın sivil toplum örgütlerinin kent- } \\
\text { leşme ve kentlileşme süreçlerine aktif } \\
\text { olarak katılımı stratejisi (G11-F3). }\end{array}$ & $\begin{array}{l}\text { Z-F stratejileri } \\
\text { 1.Kent kimliği ve kent imajının iyileştiril- } \\
\text { mesine yönelik projelerin desteklenmesi } \\
\text { stratejisi (Z5-F3) } \\
\text { 2.Kent yakını doğal peyzajın kentli halkın } \\
\text { rekreasyonel ihtiyaçlarının karşılanmasında } \\
\text { koruma-kullanım stratejisi (Z7-F7) } \\
\text { 3.Kentleşme ve yeşil alan planlamasında } \\
\text { üniversite-yerel yönetim işbirliklerinin } \\
\text { geliştirilmesi stratejisi (Z11-F5) }\end{array}$ \\
\hline 营 & $\begin{array}{l}\text { G-T stratejileri } \\
\text { 1.Şeffaf yönetim ve halkın planlama } \\
\text { süreçlerine katılımı ile uygunsuz yapı- } \\
\text { laşma baskısının azaltılması stratejisi } \\
\text { (G8-T1). } \\
\text { 2.Kentsel yenilenmede doğal afetler ve } \\
\text { deprem öncelikli planlama stratejisi (G3- } \\
\text { T4). } \\
\text { 3.Açık alanların aktif yeşil alanlara dönü- } \\
\text { şümü ile çevresel sorunların azaltılması } \\
\text { stratejisi (G4-T9). }\end{array}$ & $\begin{array}{l}\text { Z-T stratejileri } \\
\text { 1.Kent yakını tarım alanlarının amaç dışı } \\
\text { kullanımının uzun dönemli planlama } \\
\text { stratejileri ile korunması stratejisi (Z12-T2). } \\
\text { 2.Çevre yolunu da içine alan yeni ve etkin } \\
\text { bir yaya-araç ulaşım planlamasının hazır- } \\
\text { lanması stratejisi (Z20-T11). } \\
\text { 3.Mali kaynakların yetersizliği sonucu } \\
\text { arzulanan fiziki gelişimin kent yakını doğal } \\
\text { kaynakların korunması yolu ile sağlanması } \\
\text { stratejisi (Z10-T8). }\end{array}$ \\
\hline
\end{tabular}

\section{Tartışma ve Sonuç}

Geçmişten günümüze Bingöl ilinin kentleşme sürecinde geldiği aşamada olumlu ve olumsuz yönlerinin ele alındığı bu araştırmada çok yönlü sonuçlar elde edilmiştir. Araştırma sonuçları sayısal veriler ve katılımcı yaklaşımla ele alınan SWOT analizi sonuçlarından elde edilmiştir. Sayısal veriler nüfus değişimleri ve beraberinde kentin fiziki gelişimi sonuçlarına dayanırken SWOT analizinde bu değişimlerin kentleşme ve yeşil alan planlaması bakımından günümüze yansımaları ele alınmıştır. Sayısal veriler temelinde en net bulgu kent merkezi nüfusunun Bingöl'ün vilayet olarak ilan edildiği 1936 yılından günümüze kadar yüksek oranlarda arttı̆̆ı, ulaşlabilen nüfus sayım sonuçlarından 1960-2018 yılları arasında 58 yıllık süreçte 13 katlık artış meydana geldiği görülmektedir. Bir taraftan kent merkez nüfusu artarken diğer taraftan kent merkezi yerleşim alanı da büyümüştür. 1985 ile 2019 yılları arasında 
belediye mücavir alanı da dikkate alınarak yapılan hesaplamada 34 yıllık süreçte \%142'lik büyüme meydana gelmiştir. Aynı dönemde kent merkez nüfusunun \%244 oranında arttı̆g düşünüldügünnde nüfusa oranla yerleşim alanlarının daha düşük oranda arttığı görülmektedir. Bu sonuçlar kentsel dönüşümün dikey yapılaşmaya yol açtı̆̆ını göstermektedir. Aynı zamanda yeşil alana dönüştürülebilecek açık alanların yapılaşmaya açıldığını da göstermektedir.

Araştırma alanının gerek nüfus değişimleri gerekse de alansal büyümesi kadar bu büyümelerin kentleşme sürecini nasıl etkilediği ve yönetildiği de önemlidir. Yapılan SWOT analizi sonucunda kentleşme sürecinde zayıf yönlerin hem sayısal bakımdan hem de sorun derecesi bakımından daha yüksek olduğu görülmektedir. "Çarpık ve plansız yapılaşma" en yüksek oranda zayıf yön olduğu tespit edilmiştir. Bununla bağlantılı olarak kentsel dönüşüm üzerinde uygun olmayan yapılaşma talepleri ve yapısal rant baskısının kentin gelişimi üzerinde önemli bir tehdit unsuru olarak görüldüğü belirlenmiştir. Esasen huzlı ve düzensiz kentleşme sadece Bingöl İlinin bir sorunu olmayıp Türkiye kentlerinin birçoğunun en temel sorunudur (Tatllı̆ığlu, 2015, s.47).

Kentsel planlama kentlerin büyümesinde etkili olan önemli bir faktördür. Kentler merkezi bir plan ile geliştiğinde insanların günlük yaşantılarının düzgün bir şekilde sürdürülmesi ve kent içindeki yoğunluğun olumsuz etkilerinin daha az hissedilmesini sağlamaktadır. Karmaşık bir düzene sahip olan kentlerde halkın yaşam kalitesi düşmektedir (Şarkaya İçellioğlu, 2014, s. 39). Hızlı ve plansız kentleşmenin temelinde günübirlik çözümlerin ve etkili olduğu uzun dönemli planlama stratejilerinin ortaya konulmamasını önemli rolü vardır. Kentsel planlama kentlerin arazi yönetiminde ve gelişiminin kontrol edilmesinde yol gösterici belge niteliğindedir (Deng, et al., 2018, s. 126). Ancak planlama kadar planlama yönteminin belirlenmesi de oldukça önemlidir. Tüm fiziki planlamalarda olduğu gibi kentsel planlamanın da paydaş katılımlı stratejik yönetim anlayışıyla ele alınması gerekmektedir. Planlamada kent paydaşlarının da sorumluluk alması, kendi yaşam alanlarının geleceğinde söz sahibi olmaları bakımından önemlidir (Güven, 2017, s.1060, Faehnle, et al., 2014, s.141).

Araştırma kapsamında yapılan SWOT analizi ile belirlenen 23 zayıf yön içerisinde dört faktör kent planlaması ile ilgili içeriklere sahiptir. Kent için uzun dönemli yerel planlama stratejilerin olmaması, paydaş katılımını sağlamak adına ihtiyaç duyulan sivil toplum örgütlenmesinin oluşturulamaması ve kamu-yerel yönetim-üniversite işbirliklerinin geliştirilmemiş olması önemli zayıf yönler içerisinde yer almaktadır. Planlamaya katılım açısından 
kentlilik bilincinin artması ve yerel kamuoyu talepleri güçlü yön, kentin coğrafi konum açısından büyük şehirlere yakınlığı, kalkınmada birinci derece il olması, nüfus yoğunluğunun az genç nüfusun fazla olması ve kentte üniversitenin bulunması fırsat olarak değerlendirilmiştir. Bu sonuçlar planlama başlığı altında zayıf yön olarak kabul edilen unsurların güçlü yön ve fırsatlarla iyileştirilmesinin mümkün olacağını göstermektedir.

Kent planlamasını etkileyen diğer bir unsur kentlerin kurumsal kapasiteleridir. Türkiye'de kentlerin büyük oranda planlanmasından, gelişimlerinden ve kentsel sorunlarla mücadeleden birinci derecede yerel yönetimler sorumludur (Güven, 2017, s.1048). Bingöl gibi Türkiye ölçeğinde orta, dünya ölçeğinde küçük kentler, büyüyen nüfusun temel ihtiyaçlarını yönetebilecek kurumsal kapasiteye sahip değildirler. Küçük şehirler büyük şehirlere göre daha hızlı büyümektedir. Şehirler büyüdükçe ve geliştikçe yönetme görevi gittikçe karmaşık hale gelmektedir. ABD Ulusal Bilimler Akademisi'nin 90'dan fazla ülke verilerine dayanarak hazırladığı rapora göre küçük şehirlerde yaşayanlar kentleşmenin getirdiği birçok problemler ve temel hizmetler açısından daha dezavantajlı durumdadır (Antrop, 2004, s. 9; Wang, 2018, s. 75). Nitekim araştırma alanında yerel yönetimlerin örgütlenme yapısındaki eksiklikler ve uzman personel eksikliği kurumsal kapasite başlığı altında zayıf yön olarak kabul edilmiştir. Bu durumun imar ve kentleşme mevzuatın uygulanamaması sonucunu doğurduğu belirlenmiştir. Ayrıca akıllı kent uygulamalarından ve teknolojik yeniliklerden yararlanılamadığı da zayıf yön olarak görülmektedir. Bu nedenle yerel yönetimlerin her şeyden önce yeterli sayıda uzman teknik personel eksikliğini gidermesi ve kurumsal örgütlenmesini güçlendirmesi gerekmektedir.

Kentleşmenin getirdiği bir diğer sonuç kentsel alt yapı sorunlarıdır (Yüksel, 2004, s.8). Hızlı kentleşme su ve kanalizasyon yönetimi, katı atık yönetimi, ulaşım yönetimi, çevre yönetimi, toprak yönetimi gibi çok yönlü alt yapı hizmetlerinin sunulmasında zorluklara neden olmaktadır (Özel, 2005, s.139, Özdemir ve Özekicioğlu, 2006, s.24). Bingöl ilinde temel alt yapı hizmetlerinin sunulması ve sorunların yönetimi ile ilgili bir takım zayıf yön ve tehdit unsurları belirlenmiştir. Kentsel alt yapı sorunları (temiz su, kanalizasyon, çöp, yol, kaldırım...), sosyal ve sportif faaliyet alanlarının azlı̆̆ı, kent mobilyalarının ve donatı elemanlarının (aydınlatma, yönlendirme levhaları, tabelalar...) yetersizliği Bingöl ilinin kentleşme sürecinde kentsel alt yapıya yönelik zayıf yönlerdendir. Ağır geçen kış şartları, deprem ve giderek artan küresel çevre sorunları kentsel alt yapıyı etkilemesi muhtemel tehdit unsurları olarak katılımcılar tarafından belirlenmiştir. 
Kentlerin genişleme sürecinde göz ardı edilen en önemli hususlardan bir tanesi ekolojik alt yapıdır. Kent planlaması yapılırken ekolojik alt yapının korunması ve ekolojik gelişim planlarının hazırlanması sağlanmalıdır (Atıl vd., 2005, s.222). Yapılaşmanın doğal ekolojik alt yapı üzerine olan baskılarının azaltılmasının yanında kentlerin sürdürülebilirliğinin sağlanması da hedeflenmektedir. Sürdürülebilir bir kentin temel özelliği doğal kaynaklara en az zararın verilmesi, uzun ve verimli ekonomik gelişmenin mümkün kılınması, kentin kendisini enerji ve materyal açısından kararlı bir sistem dâhilinde sürdürerek kentlinin refahını sağlamasıdır (Cohen, 2006, s.63; Tuğaç 2019, s.734).

Kentlerin ekolojik alt yapısında yeşil alanların önemli rolü vardır. Yeşil alanlar kentin fiziki gelişimine yön verme, kent kimliğini oluşturma ve görsel cazibesinin artırılmasında etkin olarak kullanılmaktadır. Kentlerin etrafında yer alan orman alanları yüksek oranda şehirleşmenin baskısını azaltmada büyük bir koruma derecesine sahiptir (Fahey and Casali, 2017, s.23,). Orman alanları üzerinde öngörülen her bir koruma stratejisi doğal kaynakların korunmasında ve peyzaj alanlarının parçalanmasının önlenmesinde anahtar rol oynamaktadır (Dorning, et al. , 2015, s.36). Kent yakınında ormanlık alan tesis edilmiş kentler hem halkın rekreasyonel ihtiyaçlarının karşılanması hem de kentleşme baskısının azaltılmasında önemli bir fırsata sahip durumdadır. Bu durum araştırma alanı için de geçerlidir. Araştırma alanı için yapılan SWOT analizinde kent ekolojisi için yedi zayıf yön belirlenmişken kentin yakın çevresinde bulunan doğal peyzaj elemanlarının (orman, dağ, akarsu, dere,...) bu zayıf yönlerin iyileştirilmesinde bir fırsat olduğu vurgulanmaktadır. Özellikle kentin güney batısında bulunan çamlık, su deposu ve kent ormanı mevkileri halkın rekreasyon ihtiyaçlarını karşılayarak kent parklarının bir mesire alanı olarak kullanılmasına yönelik baskıyı azaltabilecek potansiyele sahip alanlardandır (Şekil 6). Nitekim zayıf yönler içerisinde 7. sırada yer alan "Kent yakını mesire (rekreasyon) alanlarının yetersizliği ve bu ihtiyacın kent merkezindeki yeşil alanlardan karşılanma isteği sonucu yeşil alanların amacı dışında kullanılması" maddesi 3,51 ortalama ile ekolojik alt yapıya yönelik zayıf yönler arasında yer almaktadır. 


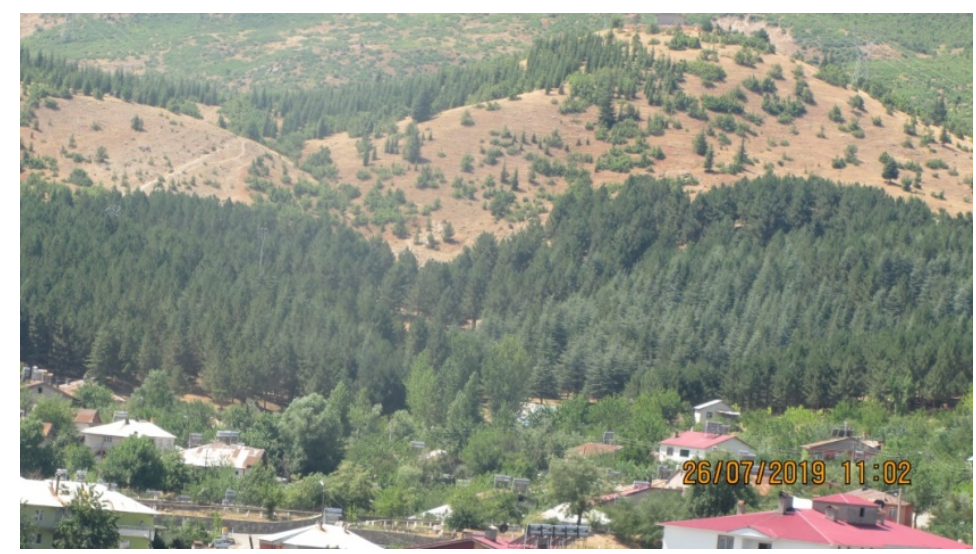

Şekil 6. Kent yakını doğal peyzajlardan bir görünüm (Çamlık mevki)

Araştırma bulguları Bingöl'ün kentleşme sürecinde yeşil alan planlamasına yeterli özenin gösterilmediğini açklamaktadır. Çalışma grubu tarafından tespit edilen 23 adet zayıf yönün yedi tanesi yeşil alanların mevcut durumunu ortaya koyduğu ve değerlendiriciler tarafından yüksek oranda puanlandığı bunun en belirgin kanıtıdır. "Kentsel açık-yeşil alanların nitelik ve nicelik bakımdan yetersizliği" 2. sırada, "Kent ekolojisi gözetilmeksizin yapılan planlamalar" 4. sırada, "Konutlarda yeterli yeşil alan bulunmaması" 6. sırada, "Kent yakını rekreasyon alanlarının yetersizliği" 7. sırada, "Yeşil alt yapı sisteminin olmaması" 8. sirada, "Mevcut su kaynaklarının kent peyzajının planlanmasına katılamaması" 9. sırada ve "Kent yakını doğal kaynakların bilinçsizce tahribatı" 10. sırada zayıf yön olarak değerlendirilmiştir. Bunun yanında yeşil alan planlamasına katkı sunabilecek güçlü yönler de bulunmaktadır. Mevcut açık-yeşil alanlar ile doğal ve kültürel peyzaj unsurları birlikte değerlendirildiğinde kentin yeşil-mavi alt yapı sisteminin kurgulanmasına uygun olması ve yeşil alana dönüştürülebilecek açık alanların fazla olması en önemli güçlü yönlerdendir. Bu kapsamda Çapakçur ve Gayt vadileri önemli bir değerdir. Nitekim su kaynağının hem kentin iklim özelliğine hem de kent formunun oluşmasına önemli katkı belirlenmiştir (Park et al. (2019, s.26). Ayrıca halkın yeşile ve doğaya karşı olumlu tutum göstermesi de güçlü yönler arasındadır. Yerleşim alanları için belirlenen fırsat ve tehdit unsurları yeşil alanlar için de geçerlidir. Amaç dışı kullanım baskıs1 en belirgin tehdit, doğal kaynak potansiyeli ise en önemli firsat olarak görülmektedir. Dolayısıyla kentin sağlıklı bir şekilde büyümesinde ve gelişmesinde yeşil alanların önemli olacağ belirgin olacağı öngörülmektedir. Bu bakımdan bir an önce uzun dönemli 
yeşil alan planlamasını ele alan yeşil alt yapı sistemi ve planlama stratejilerinin belirlenmesi gerekmektedir. Çünkü ekolojik bir gündem ne kadar erken başlatılırsa, o kadar üretken ve sistemik olabilir. Kentleşmenin geleceğini sadece demografik gelişmeler ve yerleşim alanlarının gelişmesi üzerine kurgulamak yanlıştır. Bu unsurlarla beraber peyzajı da kentleşme sürecinde ana gündem maddesi olarak elde tutmak gerekir (Wang, 2018, s.39).

Sonuç olarak, araştırma bulguları Bingöl ilinin hızlı nüfus artışı ve kentleşmenin bir sonucu olarak çok sayıda zayıf yönünün ortaya çıttğı belirlenmiştir. Bunların içerisinde çarpık ve plansız yapılaşmanın her geçen gün kendini iyice hissettirdiği, kent bir taraftan fiziki olarak büyürken diğer taraftan yeşil alt yapının ihmal edildiği görülmektedir. Ancak kentin, zayıf yönlerinin iyileştirilmesine destek olabilecek firsatlara da sahip olduğu belirlenmiştir. Güçlü yönleri ortaya çıkaracak zayıf yönleri ise ortadan kaldıracak planlama stratejilerinin geliştirilmesi önerilmektedir. Bu nedenle vakit kaybetmeksizin bir an önce Tablo 6'da örnek olarak verilen kentsel gelişim ve yeşil alan planlama stratejileri benzeri stratejilerin belirlenerek fiziki planların hazırlanması ve uygulanması gerekmektedir. Bununla beraber bütün planlama politikalarının stratejik yönetim anlayışı gereği şeffaflık ilkesi doğrultusunda ve katılımcılık esası içerisinde yürütülmesinin kentin geleceği için önemli olduğu belirlenmiştir. Ancak bunları başarabilmek için özellikle yerel yönetimlerin mali, teknik, hukuki ve insan kaynağı bakımından merkezi hükümet tarafından desteklenmesi gerekmektedir. Yerelde ise başta üniversiteler olmak üzere valilik, diğer kamu kurumları, sivil toplum örgütleri, yerel halk ve iş insanlarının yerel yönetimlere katkı sunması beklenmektedir.

\section{Teşekkür}

Bu araştırma, "Bingöl Kent Merkezi Açık-Yeşil Alanların Yeterliliği, Kentleşme ile İlgili Temel Sorunlar ve Gelişim Senaryolarının Çoklu Araştırma Yöntemleri Kullanımı ile Belirlenmesi" isimli BAP-ZF.2018.00.011 no'luBÜBAP projesi tarafından desteklenmiştir. Proje kapsamında maddi ve manevi katkılarından dolayı Bingöl Üniversitesine teşekkür ederiz. 


\title{
Extended Abstract
}

\section{Assessment of Urban Development and Green Area Planning Process by Participant Swot Analysis Method: A Case of Bingol Province}

\author{
Hüccet Vural \\ Alperen Meral \\ Bingöl University \\ Bingöl University \\ Sülem Ş. Doğan \\ Bingöl University
}

Urbanization, which is supposed to start with the industrial revolution in the real sense, has caused three basic problems for humanity at the beginning of the 21st century. These problems are global population growth, urbanization and degradation of ecosystem. Improvement of human living standards and technological developments reveal the desire to live in a better environment. The social, economic and cultural opportunities of the city centers are more attractive than rural areas, which have increased the migration to the city centers.

Unplanned, unscheduled and random construction, deterioration of the urban fabric and damage to the ecosystem reveal unplanned urbanization. Distorted and irregular construction becomes more complex with poor governance of the city. On the other hand, city administration is the job of taking the necessary decisions, applying and controlling the results for the most accurate and healthy use of financial, human, physical and natural resources in line with the needs of the current population and the future population.

Today, the city management requires an understanding that attaches importance to participation and transparency. A planning approach that needs and requires considering the economic, cultural and social values of the stakeholders should be put forward. In addition, long-term and transparent plans and policies will ensure a healthy city. In line with central government policy of urban management in Turkey this is carried out by local governments. In this respect, it is possible to see planning policies that vary from region to region in urban management planning. It's known that the current urban planning is mostly handled at a higher scale. There are problems regarding the local implementation of the prepared plans and prob- 
lems in reaching the plan-program targets. Indeed, Turkey frequently voiced their inability distorted by unplanned urbanization and green areas of the city can be regarded as being mainly driven by the lack of planning.

Bingöl, which is selected as the research area of this study, has a similar situation. The lack of a formal strategy document addressing the long-term sustainable urbanization and green space planning strategies of the city were the basis for this study. In this research, it's aimed to reveal the current status of the relationship between urbanization process and green area planning of Bingöl province and to address urbanization strategies in line with economic, administrative and political changes with a participatory approach. In addition, in the process of urban development, it's aimed to identify the strengths and weaknesses related to the internal factors affecting the urbanization-landscape relationship and the opportunities and threats arising from external factors.

In this research, SWOT and TOWS methods, which are known as planning and strategy determination tools, were used. SWOT analysis is a method used to analyze the internal and external factors in a subject related to a region or institution and to present the current situation. However, the most common limitation of these methods is the determination of decision factors in small groups of 2-3 people and the importance of these factors cannot be quantified. In order to eliminate this deficit, 18 working groups and 41 evaluation groups were formed and the research findings were obtained. The opinions obtained from the study group were subjected to content analysis and 62 internal-external factors were determined. In order to determine the priorities and advantages of the determined factors within themselves, 41 evaluators were submitted to the scoring of the group. Scoring was made between 0-4 points; the number " 0 " is used to indicate "disagree" and "1, 2, 3, 4 " figures involvement (1 lowest, 4 highest)" were used to specify. In addition, planning strategies were developed by using TOWS (strategic analysis) with the interaction of internal and external factors. Furthermore, planning strategies have been developed by using TOWS (strategic analysis) with the interaction of internal and external factors.

First of all, when the change of the population which is the main factor affecting urbanization is examined; The population of Bingöl Province was 131,364 in 1960 and in 2018 it was 281,205 (with an increase of 114,07\%).On the other hand, the population of the city center increased from 8.526 to 117.556 in 58 years and the percentage increase is $1279 \%$ (approximately 13 times). The basic urbanization rate increased from $11.21 \%$ to $59.81 \%$. While 
the population of the city center increased on the one hand, the settlement area of the city center also grew.

As well as population changes and spatial growth of the research area, how these growths affect and manage the urbanization process is important. As a result of the SWOT analysis, it is seen that the weaknesses in urbanization process are higher in terms of both numerical and problem level. "Distorted and unplanned construction" is the weakest aspect, "natural structure of the city is suitable for the construction of the green and blue infrastructure system" is the strongest aspect, "unplanned and improper construction pressure on urban transformation, demand for rent" biggest threat, "the geographical position of the city and proximity to metropolitan cities" is seen as the biggest opportunity factor.

One of the most important issues ignored in the process of enlargement are the ecological infrastructure. The findings of the study explain that Bingöl is not paying enough attention to the planning of green areas during the urbanization process. Seven of the 23 weaknesses identified by the study group reveal the current state of the green areas and are highly rated by the evaluators.

As a result, it's determined that as an outcome of rapid population growth and urbanization of Bingöl province, many weaknesses have emerged. It's seen that the skewed and unplanned construction makes itself felt with each passing day, while the city grows physically on one side the green infrastructure is neglected on the other. However, it has been determined that the city also has opportunities to support the improvement of its weaknesses. It's recommended to develop planning strategies to eliminate the weaknesses that will reveal the strengths and to prepare long-term urban development plans with the participation of different disciplines. However, it's determined that it's important for the future of the city that all planning policies are carried out in line with the principle of transparency and participation compatibly the strategic management approach. However, in order to achieve these, local governments need to be supported by the central government, especially in terms of financial, technical, legal and human resources. At the local level, it's expected that governors, especially public universities, other public institutions, non-governmental organizations, local people and business people will contribute to local governments. 


\section{Kaynakça/References}

Abo-El-Wafa, H., Yeshitela, K. ve Pauleit, S. (2018). The use of urban spatial scenario design model as a strategic planning tool for Addis Ababa. Landscape and Urban Planning, 180, 308-318.

Aksoy, Y. Ve Ergun, N. (2009). Kentleşme ve yeşil alan sorunu üzerine bir araştırma İstanbul kenti Bakırköy ilçesi örneği. TÜBAV Bilim Dergisi, 2(4), 426-438.

Anonim, (2010). Bütünleşik kentsel gelişme stratejisi ve eylem planı (2010-2023). http://www.sp.gov.tr/upload/xSPTemelBelge/files/bk0sC+KENTGES.pdf adresinden erişilmiştir.

Anonim, (2016). Bingöl ili sosyal analiz çalışması. Ankara:Hegem Vakfı Yayınları, ISBN: 978-605-8295-10-0,

Anonim, (2017). Şehircilik şûrası bilgilendirme kitapçığı. Çevre ve Şehircilik Bakanlığı, www.csb.gov.tr/projeler/sehirciliksurasi/ adresinden erişilmiştir.

Antrop, M. (2004). Landscape change and the urbanization process in Europe. Landscape and urban planning, 67(1-4), 9-26.

Aslı, A., Gülgün, B. ve Yörük, İ. (2005). Sürdürülebilir kentler ve peyzaj mimarl1ğ1. Ege Üniversitesi Ziraat Fakültesi Dergisi, 42(2), 215-226.

Belde, (2006). Planlama sürecinin yenilenmesi projesine ait etüt ve teşhis evresi: Tasarmm evresi süreci. Final Raporu TC Bayındırlık ve İskân Bakanlığı Teknik Araştırma ve Uygulama Genel Müdürlüğü.

Cohen, B. (2006). Urbanization in developing countries: Current trends, future projections, and key challenges for sustainability. Technology in society, 28(1-2), 63-80.

Deng, Y., Fu, B. ve Sun, C. (2018). Effects of urban planning in guiding urban growth: Evidence from Shenzhen, China. Cities, 83, 118-128.

Doğan, S. Ş. ve Yılmaz, S. (2019). Coğrafi Bilgi Sistemleri ve Uzaktan Algılama Yöntemleri ile Arazi Örtüsü/Alan Kullanım Değişimlerinin Belirlenmesi: Bingöl Kent Merkezi Örneği. Türk Tarım ve Doğa Bilimleri Dergisi, 6(3), 536-545.

Dorning, M. A., Koch, J., Shoemaker, D. A. ve Meentemeyer, R. K. (2015). Simulating urbanization scenarios reveals tradeoffs between conservation planning strategies. Landscape and Urban Planning, 136, 28-39.

Esen, F. (2019). Coğrafi bilgi sistemleri (CBS) ve uzaktan algilama (UA) ile Bingöl Şehri ve çevresindeki yerleşmelerin mekânsal gelişimi için uygun alanların tespit edilmesi. Anemon Muş Alparslan Üniversitesi Sosyal Bilimler Dergisi, 7(2), 101-112.

Faehnle, M., Bäcklund, P., Tyrväinen, L., Niemelä, J. ve Yli-Pelkonen, V. (2014). How can residents' experiences inform planning of urban green infrastructure? Case Finland. Landscape and Urban Planning, 130, 171-183.

Fahey, R. T. ve Casali, M. (2017). Distribution of forest ecosystems over two centuries in a highly urbanized landscape. Landscape and Urban Planning, 164, 13-24.

Gavrilidis, A. A., Niță, M. R., Onose, D. A., Badiu, D. L. ve Năstase, I. I. (2019). Methodological framework for urban sprawl control through sustainable planning of urban green infrastructure. Ecological Indicators, 96, 67-78. 
Güven, A. (2017). Kentsel sorunların çözümünde kent yönetimi ve paydaşlarının rolü. Journal of International Social Research, 10(52).

İçellioğlu, C. Ş. (2014). Kent turizmi ve marka kentler: turizm potansiyeli açısından İstanbul'un swot analizi. Sosyal Bilimler Dergisi, (1), 37-55.

Kan, C. (2018). Bingöl şehrinin depremselliği ve yerleşme ilişkisi. Yayınlanmamış Yüksek lisans Tezi, Kahramanmaraş Sütçü İmam Üniversitesi Sosyal Bilimler Enstitüsü Coğrafya Anabilim Dalı, Kahramanmaraş.

Manavoğlu, E., Ortaçeşme, V. (2007). Konyaaltı kentsel alanında bir yeşil alan sistem önerisi geliştirilmesi. Akdeniz Üniversitesi Ziraat Fakültesi Dergisi, 20(2), 261-271.

Mehmet, Ö. (2005). Kentsel gelişme ve kentleşme sürecinde Niğde. Karamanoğlu Mehmetbey Üniversitesi Sosyal ve Ekonomik Araştırmalar Dergisi, 2005(2), 120-144.

Özdemir, Z., Özekicioğlu, A. (2006). Kentleşme ve çevre sorunları. Süleyman Demirel Üniversitesi İktisadi ve İdari Bilimler Fakültesi Dergisi, 11(1), 17-30.

Özden, P. P. (2010). Türkiye'de kentsel dönüşüm politikaları ve uygulamalarına eleştirel bir bakış. (Der. D. Özdemir), Kentsel Dönüşümde Politika, Mevzuat ve Uygulama, Avrupa Deneyimi, İstanbul Uygulamaları, içinde 1-22.

Park, C. Y., Lee, D. K., Asawa, T., Murakami, A., Kim, H. G., Lee, M. K. ve Lee, H. S. (2019). Influence of urban form on the cooling effect of a small urban river. Landscape and urban planning, 183, 26-35.

Soylu, H. (2009). Bingöl'de hızlı şehirleşmeden kaynaklanan çevre sorunları. Atatürk Üniversitesi Sosyal Bilimler Enstitüsü Dergisi, 13(1), 87-104.

Steiner, F. (2014). Frontiers in urban ecological design and planning research. Landscape and Urban Planning, 125, 304-311.

Tatlılıoğlu, K. (2015). Kentleşme ve sürdürülebilir kalkınma sürecinde Bingöl ilinin sosyo-kültürel ve ekonomik durumu üzerine genel bir değerlendirme. Bingöl Araştırmaları Dergisi, 2(1), 29-54.

Tuğaç, Ç. (2018). Uluslararası sürdürülebilir kent ölçütleri bağlamında Türkiye için bir değerlendirme. Kent Akademisi, 11(36), 703-740.

Türkiye İstatistik Kurumu [TÜİK], (2018). Adrese dayalı nüfus kayıt sistemi sonuçları http://tuik.gov.tr/Start.do adresinden erişilmiştir.

Üstündağ, Ö. (2011). Bingöl şehir merkezinin doğal ortam analizi ve fiziksel planlaması. Yayınlanmamış Doktora Tezi, Fırat Üniversitesi Sosyal Bilimler Enstitüsü Coğrafya Anabilim Dall, Elazı̆̆.

Wang, Z. (2018). Evolving landscape-urbanization relationships in contemporary China. Landscape and Urban Planning, 171, 30-41.

Yılmaz, E., Çiftçi, S. (2011). Kentlerin ortaya çıkışı ve sosyo-politik açıdan Türkiye'de kentleşme dönemleri. Elektronik Sosyal Bilimler Dergisi, 10(35), 252-267. 